\title{
Manajemen Pembelajaran dalam Meningkatkan Prestasi Belajar Siswa di MTs Jam'iyah Mahmudiyah
}

\author{
Neliwati ${ }^{1}$, Isra Adawiyah Siregar ${ }^{2}$, Lia Ariska Ritonga, ${ }^{3 *}$ \\ ${ }^{1}$ (Universitas Islam Negeri Sumatera Utara Medan) \\ ${ }^{3}$ (Universitas Islam Negeri Sumatera Utara Medan) \\ ${ }^{2}$ (Universitas Islam Negeri Sumatera Utara Medan)
}

* Corresponding Author. E-mail: liaariskaritonga30@gmail.com

\begin{tabular}{|l|l|l|}
\hline Receive: 23/05/2021 & Accepted: 13/07/2021 & Published: 01/10/2021
\end{tabular}

\begin{abstract}
Abstrak
Penelitian ini bertujuan untuk mengetahui manajemen pembelajaran dalam meningkatkan prestasi belajar siswa di MTs Jam'iyah Mahmudiyah. Riset ini berusaha untuk menjelaskan tentang bagaimana manajemen pembelajaran dan bagaimana prestasi belajar siswa yang ada di MTs Jam'iyah Mahmudiyah. Metode yang digunakan dalam penelitian ini adalah kualitatif. Tekhnik pengumpulan data menggunakan tekhnik observasi, wawancara dan tekhnik studi dokumentasi untuk memperoleh data yang valid tentang manajemen pembelajaran dalam meningkatkan prestasi belajar siswa. Riset ini dilakukan di MTs Jam'iyah Mahmudiyah yang berada di Jl. Syekh M. Yusuf Kecamatan Tanjung Pura. Adapun hasil penelitian diketahui bahwa Pelaksanaan Manajemen pembelajaran secara umum sudah cukup baik, dengan ditandai perencanaan yang mencakup program tahunan, semesteran, silabus, kalender pendidikan, dan RPP, pada perencanaan masih ada cela yang kurang baik, dikarenakan masih banyak program yang belum dirancang dan dibuat serta prestasi belajar sebagai hasil yang dicapai oleh peserta didik setelah mengalami suatu proses belajar dalam jangka tertentu, hasil belajar siswa mencakup ranah kognitif, afektif dan psikomotorik. Prestasi belajar siswa di MTs Jam'iyah Mahmudiyah sudah cukup baik yang ditandai dengan: Nilai beberapa pelajaran siswa sudah memenuhi taget KKM, penerapan amalan Agama sudah dilaksanakan dalam kehidupan sehari-hari peserta didik dan siswa MTs Jam'iyah Mahmudiyah telah menjuarai lomba-lomba dalam even-even dengan predikat baik.
\end{abstract}

Kata Kunci: Prestasi, Manajemen, Siswa

\section{Abstract (English-Indonesia)}

This study aims to determine learning management in improving student achievement at MTs Jam'iyah Mahmudiyah. This research seeks to explain how learning management is and how student achievement is at MTs Jam'iyah Mahmudiyah. The method used in this research is qualitative. Data collection techniques using observation techniques, interviews and documentation study techniques to obtain valid data about learning management in improving student achievement. This research was conducted at MTs Jam'iyah Mahmudiyah which is located on Jl. Sheikh M. Yusuf, Tanjung Pura District. The results of the study show that the implementation of learning management in general is quite good, marked by planning that includes annual programs, semesters, syllabus, educational calendars, and lesson plans, in planning there are still flaws that are not good, because there are still many programs that have not been designed and made and learning achievement as a result achieved by students after experiencing a learning process within a certain period, student learning outcomes include the cognitive, affective and psychomotor domains. Student learning achievement at MTs Jam'iyah Mahmudiyah is quite good which is marked by: The value of several student lessons has met the KKM target, the application of religious practices has been carried out in the daily lives of 
students and students of MTs Jam'iyah Mahmudiyah have won competitions in events with good predicates.

Keywords: Performance, anagement, Students

\section{Pendahuluan}

Pendidikan merupakan usaha sadar yang dilakukan manusia dalam meningkatkan kualitas dirinya. Oleh karena itu upaya untuk memajukan pendidikan sangat digalakkan oleh pemerintah. Karena maju mundurnya suatu negara ditentukan oleh kualitas pendidikannya. Tentu hal ini sangat berkaitan dengan prestasi belajar siswa dalam lembaga pendidikan.

Prestasi Belajar dapat diartikan sebagai hasil yang dicapai oleh individu setelah mengalami suatu proses belajar dalam jangka waktu tertentu. Prestasi belajar juga diartikan sebagai kemampuan maksimal yang dicapai seseorang dalam suatu usaha yang menghasilkan pengetahuan atau nilai - nilai kecakapan. Di sekolah hasil belajar dinyatakan dalam angka-angka (nilai) dalam semua mata pelajaran yang diberikan. Jadi bentuk angka (nilai) ini merupakan lambang untuk prestasi (hasil belajar siswa).

Pada kenyataannya faktor-faktor penyebab rendahnya prestasi belajar, karena diakibatkan jika dalam proses pembelajaran berlangsung siswa lebih memilih untuk tidak masuk kelas pada jam pertama mata pelajaran. Alasan terlambat karena jarak rumah yang jauh dengan sekolah, serta ada beberapa siswa juga yang sering terlambat karena sebelum berangkat ke sekolah harus membantu orang tuanya karena keadaan ekonomi. Selain itu, ada beberapa siswa yang sering bolos atau berada di luar kelas pada saat pembelajaran berlangsung. Hal ini disebabkan sebagian siswa yang tidak mengerjakan tugas yang diberikan guru sehingga mereka takut masuk di dalam kelas, dengan alasan takut akan dihukum, dan merasa bosan di dalam kelas. Sebagian siswa lain juga sering bolos dengan alasan merasa bosan dengan mata pelajaran tertentu maupun ada pengaruh teman dari luar sekolah. Ada pula siswa yang sering alpa akibat keluarga yang broken home sehingga mereka merasa malas untuk ke sekolah. Bahkan ada siswa yang sering keluar masuk pada saat proses pembelajaran berlangsung dan kurang memperhatikan guru pada saat mengajar, baik siswa laki-laki maupun perempuan. Hal ini terjadi karena adanya pengaruh faktor dari dalam diri siswa maupun dari luar sehingga mereka mengesampingkan belajar. Akibatnya siswa yang sering melakukan hal ini akan ketinggalan materi pelajaran, sehingga hasil evaluasi tidak mencapai nilai ketuntasan yang sudah ditentukan.

Melihat fakta yang terjadi di lapangan bahwa perilaku di atas akan membawa dampak buruk bagi siswa seperti resiko akan ketinggalan materi pelajaran, bahkan bisa saja tidak naik kelas. Dengan ketinggalan pelajaran siswa tidak dapat menjawab ketika diadakan evaluasi maupun ulangan, sehingga akan terlihat hasil yang dicapai siswa tidak mencapai taraf ketuntasan. Melihat realita yang demikian memprihatinkan, maka salah satu agenda penting dalam proses pembelajaran adalah bagaimana caranya agar siswa dapat lebih bersemangat lagi dalam proses penerima pelajaran, sehingga akan berpengaruh pada peningkatan prestasi belajarnya. Berbagai macam cara yang ditempuh agar prestasi berhasil dengan baik, sebab keberhasilan tersebut bukan hanya ditentukan oleh lembaga pendidikan atau pendidik, tetapi ditentukan juga oleh karakteristik siswa itu sendiri. Dengan demikian, upaya peningkatan kualitas pendidikan harus dimulai dengan pembenahan manajemen sekolah, disamping peningkatan kualitas guru dan pengembangan sumber pendidikan. Agar semua unsur terlibat dalam proses pembelajaran dapat bersinergi diperlukan manajemen untuk mengelola, mengatur dan menata semua unsur pembelajaran, dengan kata lain manajemen pembelajaran. Manajemen pembelajaran merupakan tugas yang dilakukan oleh seorang guru, tugas tersebut meliputi perencanaan, pelaksanaan dan evaluasi pembelajaran. Berdasarkan dari latar belakang diatas, maka penulis ingin mengangkat permasalahan tersebut dalam penelitian yang berjudul "Manajemen Pembelajaran Dalam Meningkatkan Prestasi Belajar Siswa di MTs Jam'iyah Mahmudiyah" .

\section{Metode}

Riset ini dalam penelitiannya menggunakan metode penelitian kualitatif. Margono (1997: 45) menyatakan penelitian kualitatif adalah suatu proses penelitian untuk 
memperoleh data deskriptif dari kata-kata yang tertulis maupun secara lisan dari narasumber / sampling yang dapat dimintai informasi. Penelitian kualitatif adalah penelitian yang bermaksud untuk memahami fenomena tentang apa yang dialami oleh subjek penelitian dengan cara deskripsi dalam bentuk kata-kata dan bahasa, pada suatu konteks khusus yang alamiah dan dengan memanfaatkan berbagai metode alamiah. Biasanya penelitian kualitatif membutuhkan keahlian analisis, sistematis, dan ilmiah, maka akan memperoleh ketepatan dalam pemahamannya, karena hakikat dari kejadian atau gejala buat penelitian kulitatif ialah integritas atau terpadu. Penelitian kualitatif biasanya bersifat deskriptif-analitik maksudnya menganalisis terhadap isi yang disusun dan dibuat berdasarkan sistematik, ilmiah dan menyeluruh. Riset ini dilakukan di MTs Jam'iyah Mahmudiyah.

\section{Hasil dan Pembahasan}

James AF Stoner yang dikutip oleh Handoko menjelaskan bahwa manajemen merupakan proses perencanaan, pengorganisasian, pengarahan dan pengawasan usaha-usaha para anggota organisasi dan pengguna sumber daya-sumber daya organisasi lainnya agar mencapai tujuan organisasi yang telah ditetapkan. Pengertian tersebut, dapat diambil suatu pengertian manajemen merupakan ilmu yang didasari untuk melakukan sebuah pekerjaan dengan tindakan-tindakan yang terdiri dari perencanaan, pengorganisasian, penggerakan dan pengawasan yang telah ditetapkan dan ditentukan sebelumnya. Sehingga manajemen pembelajaran yakni sebagai usaha dan tindakan kepala sekolah sebagai pemimpin instruksional di sekolah dan usaha maupun tindakan guru sebagai pemimpin pembelajaran di kelas yang dilaksanakan sedemikian rupa untuk memperoleh hasil dalam rangka mencapai tujuan program sekolah dan juga pembelajaran. Langkah-Langkah Manajemen Pembelajaran diantaranya:

\section{Perencanaan Pembelajaran}

Perencanaan merupakan penetapan dan pemanfaatan sumber daya secara terpadu yang diharapkan dapat menunjang kegiatan-kegiatan dan upaya-upaya yang akan dilaksanakan secara efisien dan efektif dalam mencapai tujuan. Hal ini Gaffar menegaskan bahwa perencanaan dapat diartikan sebagai proses penyusunan berbagai keputusan yang akan dilaksanakan pada masa yang akan datang untuk mencapai tujuan yang ditentukan. Menurut Suryobroto (2002: 27) pada hakikatnya bila suatu kegiatan direncanakan dahulu maka dari kegiatan tersebut akan lebih terarah dan lebih berhasil. Itulah sebaiknya seorang guru harus memiliki kemampuan dalam merencanakan program pelajaran, membuat persiapan pembelajaran yang hendak diberikan. Perencanaan itu dapat bermanfaat bagi guru sebagai kontrol terhadap diri sendiri agar dapat memperbaiki cara pengajarannya.

2. Pelaksanaan Pembelajaran

Pelaksanaan pembelajaran merupakan proses berlangsungnya belajar mengajar di kelas yang merupakan inti dari kegiatan di sekolah. Jadi pelaksanaan pengajaran merupakan interaksi guru dengan murid untuk rangka menyampaikan bahan pelajaran kepada siswa dan untuk mencapai tujuan pengajaran. Fungsi ini memuat kegiatan pengorganisasian dan kepemimpinan pembelajaran yang melibatkan penentuan berbagai kegiatan, seperti pembagian pekerjaan ke berbagai tugas khusus yang harus dilakukan guru dan peserta didik dalam proses pembelajaran.

3. Evaluasi Pembelajaran

Menurut Nganimun Naim dan Achmad Patoni (2007: 21-24) dalam konteks manajemen pembelajaran kontrol (pengawasan) adalah suatu konsep yang luas yang dapat diterapkan pada manusia, benda dan organisasi. Evaluasi diartikan sebagai proses sistematis untuk menentukan nilai sesuatu (tujuan, kegiatan, keputusan, unjuk rasa, proses, orang objek, dan yang lain) berdasarkan kriteria tertentu melalui penilaian. Evaluasi mencakup evaluasi hasil belajar dan evaluasi pembelajaran. Evaluasi hasil belajar menekankan pada diperolehnya informasi tentang seberapakah perolehan siswa dalam mencapai tujuan pengajaran yang ditetapkan. Sedangkan evaluasi pembelajaran merupakan proses sistematis untuk memperoleh informasi tentang keefektifan proses pembelajaran dalam membantu siswa mencapai tujuan pengajaran secara optimal. Dengan demikian evaluasi hasil belajar menetapkan baik buruknya hasil dari kegiatan pembelajaran. Sedangkan evaluasi pembelajaran menetapkan baik 
buruknya proses dari kegiatan pembelajaran.

Dari hasil wawancara terhadap guru PAI dikatakan bahwa guru dalam melaksanakan pembelajaran dengan menerapkan manajemen melalui proses perencanaan pembelajaran, pelaksanaan pembelajaran dan evaluasi pembelajaran.

1. Perencanaan Pembelajaran

Perencanaan pembelajaran merupakan langkah pertama yang harus disiapkan sebelum melakukan kegiatan proses belajar mengajar yang meliputi proses bagaimana memilih, menetapkan dan mengembangkan, pendekatan, metode dan teknik pembelajaran menawarkan bahan aja, menyediakan pengalaman belajar yang bermakna, serta mengukur tingkat keberhasilan proses pembelajaran untuk mencapai hasil pembelajaran. Aktivitas yang terdapat pada pembelajaran perlu di upayakan melalui perencanaan pembelajaran yang baik, agar dapat mempengaruhi pilihan, putusan dan pengembangan kehidupan peserta didik, oleh karena itu salah satu kemampuan yang harus dimiliki guru adalah memmbuat perencanaan pembelajara secara profesional dalam melakasanakan tugas dan tanggungjawabnya sebagai seorang pendidik, pembelajar, sekaligis sebai perancang pembelajaran. Silabus merupakan rencana mata pelajaran pada suatu dan /atau kelompok yang mencakup standar kompetensi, kompetensi dasar, materi pokok pembelaaran, kegiatan pembelajaran, indikator, penilaian, alokasi waktu, dan sumber atau bahan-bahan alat belajar, silabus bertujun untuk memebantu guru dan tenaga kependidikan lainnya untuk menjabarkan perann pembeljaran.

Silabus merupakan rencana Pembelajaran. Guru MTs Jam'iyah Mahmudiyah sebagai pengembang kurikulum memiliki kreatifitas dalam mengembangkan materi dan kompetensi dasar setiap pokok bahasan sesuai dengan kompetensi yang dimiliki peserta didik dan pengembangan lingkungan sekitar. Penyusunan silabus yang dikembangkan oleh guru MTs Jam'iyah Mahmudiyah sudah sesuai dengan komponen silabus sehingga dapat memudahkan guru untuk pencapaian tujuan pelajaran yang akan di ajarkan kepada peserta didik.

Penyusunan program semester dapat ditempuh dengan menghitung hari dan jam efektif selama satu semester, mencatat mata pelajaran yang akan diajarkan selama satu cawu, membagi alokasi waktu yang tersedia selama satu semester. Program semesteran merupakan penjabaran di program tahunan. Pada program semesteran beberapa guru belum membuat program semesteran, tetapi ditargetkan Waka Kurikulum dalam waktu dekat harus sudah jadi. Program semesteran sebagai acuan dalam proses pembelajaran selama semester, walaupun sibuk tetapi alangkah baiknya guru membuat program semesteran, karena dengan adanya program ini, maka kegiatan pembelajaran dan alokasi waktu selama satu semester bisa terarah dan bisa terkondisikan dengan baik. Kalender Pendidikan merupakan rencana kegiatan yang akan dilaksanakan untuk satu tahun, Kalender Pendidikan di MTs Jam'iyah Mahmudiyah disusun atas dasar efisiensi, efektifitas kegiatan belajar mengajar.

RPP sebagai acuan guru dalam pembelajaran, adanya RPP guru bisa tahu seberapa jauh tingkat keberhasilan dan pembelajaran. Pembuatan RPP merupakan tugas guru dalam melaksanakan kegiatan pembelajaran, walaupun pembelajaran sudah sesuai dengan yang diharapkan tetapi dengan adanya RPP kegiatan pembelajaran bisa lebih efektif dan terarah. Pengembangan rencana pembelajaran harus memperhatikan perhatian dan karakeristik peserta didik terhadap materi standar yang dijadikan bahan kajian, hal ini hrus diperhatikan agar guru jangan hanya berperan sebagai transfor motor, melainkan juga harus berperan sebagai motivator yang yang dapat membangktitkan gairah dan nafsu belajar serta mendorong pesreta didik untuk belajar dengan menggunakan berbagai variasi media dan simber belajar yang sesuai, serta menunjang pembentukan standar kompetensi dan kopetensi dasar.

Menurut penulis perencanaan pembelajaran yang disusun oleh guru dapat dijadikan pedoman yang sangat membantu guru tersebut, bukan hanya dalam rangka menyajikan materi pelajaran, tetapi dapat juga dijadikan sebagai bahan evaluasi pembelajaran berikutnya dapat berjalan dengan lebih baik lagi dan lebih optimal dalam mencapai pembelajaran. Perencanaan pembelajaran di MTs Jam'iyah Mahmudiyah sudah cukup baik karena sebagian besar sudah membuat atau merancang rencana pembelajaran dah sudah sesuai dengan karateristik peserta didik untuk 
mencapai tujuan pembelajaran walaupun masih ada yang belum dirancang.

2. Pelaksanaan Pembelajaran

Pembelajaran merupakan aktualisasi kurikulum yang menuntut keaktifan guru dalam menciptakan dan menumbuhkan kegiatan perta didik sesuai dengan rencana yang telah diprogramkan. Hal ini guru harus dapat mengambil keputusan atas dasar penilaian yang tepat ketika peserta didik belum dapat membentuk kompetensi dasar. Pelaksanaan pembelajaran sangat erat kaitannya dengan peran guru dalam pembelajaran di kelas, yang akan menentukan tercapainya tujuan pembelajaran atau belum, dalam pelaksanaan pembelajaran ini meliputi pengorganisasian pembelajaran dan pengelolaan guru dalam proses pembelajaran di kelas. Pelaksanaan pembelajaran MTs Jam'iyah Mahmudiyah sudah berjalan dengan lancar, tetapi menurut peneliti guru harus lebih bisa berinteraksi dengan peserta didik, lebih memahami karaketrisik peserta didik dengan menanggapinya secara bijaksana, karena pada pelaksanaan pembelajaran di kelas kurang adanya interaksi yang edukatif.

Pelaksanaan pembelajaran di MTs Jam'iyah Mahmudiyah sudah berjalan dengan lancar, tetapi menurut peneliti guru PAI harus lebih bisa berinteraksi dengan peserta didik, lebih memahami karaketrisik peserta didik dengan menanggapinya secara bijaksana, karena pada pelaksanaan pembelajaran di kelas kurang adanya interaksi yang edukatif. Misalnya pada tahap sebelum melakukan pembelajaran guru harus bisa melihat kesediaan mental para peserta didik. Tanpa kesediaan mental siswa dalam belajar tidak akan bertahan menghadapi berbagai macam kesukaran, terutama pada saat siswa dihadapi berbagai masalah yang harus dipecahkan. Sikap mental yang perlu diusahakan oleh setiap siswa dalam rangka persiapan belajar sekurang-kurangnya mencakup 4 segi, yaitu : tujuan belajar, minat terhadap pelajaran, kepercayaan pada diri sendiri dan keuletan.

Sebelum melakukan pembelajaran hendaknya guru mengajak para peserta didik melakukan do'a bersama sebagai pembuka kegiatan proses belajar mengajar. Kemudian dilanjutkan dengan guru mengadakan pencatatan terhadap peserta didik yang hadir (presensi), tak hadir (absensi) dan yang datang terlambat, selanjutnya guru memberikan apersepsi.
Setelah kegiatan absensi selesai masuklahlah pada tahap pemberian bahan pelajaran dengan menjelaskan kepada siswa tujuan pengajaran pokok materi yang akan bahas dan yang sudah dituliskan, Pada setiap pokok materi yang dibahas sebaiknya diberikan contoh-contoh yang kongkret, pertanyaan, tugas. Penggunaan alat bantu pengajaran untuk memperjelas pembahasan pada setiap materi pelajaran. Menyimpulkan hasil pembahasan dari semua pokok materi. pelaksanaan pembelajaran guru menggunakan pendekatan Rasional, pendekatan emosinal dan pendekatan keteladanan. Dan dengan menggunakan beberapa metode, ceramah, Tanya jawab, demontrasi, diskusi, metode ini merupakan metode yang diterapkan oleh semua guru mata pelajaran sebagainmana upaya untuk mengembangkan pola pikir peserta didik, metode ini dinilai efektif dalam meningkatkan motivasi siswa dalam menguasai materi yang akan dibahas pada pertemuan berikutnya. Selain metode media pembelajaran yang digunakan sesuai materi yang diajarkan, kreatifitas guru dalam media sangat berpengaruh dalam keberhasilan pembelajaran.

3. Evaluasi Pembelajaran

Evaluasi bertujuan untuk menjamin kinerja yang dicapai agar sesuai rencana dan tujuan yang telah ditetpkan. Guru sebagai menejer pembelajaran harus mengambil kstrategi dan tindakan perbaikan apabila terdapatkesenjangan antara proses pembelajaran yang terjadi secara aktual dengan yang telah direncanakan pada program pembelajaran. Evaluasi pembelajaran harus dilakukan terus menurus untuk mengetahui dan memantau perubahan serta kemajuan yang dicapai peserta didik, maupun untuk memberi sekor, angka atau nilai yang biasa dilakukan pada penilaian hasil belajar. Evaluasi mencakup evaluasi hasil belajar dan evaluasi pembelajaran. Evaluasi hasil belajar menekankan pada diperolehnya informasi tentang seberapakah perolehan siswa dalam mencapai tujuan pengajaran yang ditetapkan. Sedangkan evaluasi pembelajaran merupakan proses sistematis untuk memperoleh informasi tentang keefektifan proses pembelajaran dalam membantu siswa mencapai tujuan pengajaran secara optimal.

Evaluasi mencakup evaluasi hasil belajar dan evaluasi pembelajaran. Evaluasi hasil belajar menekankan pada diperolehnya informasi tentang seberapakah perolehan siswa dalam mencapai tujuan pengajaran yang 
ditetapkan. Sedangkan evaluasi pembelajaran merupakan proses sistematis untuk memperoleh informasi tentang keefektifan proses pembelajaran dalam membantu siswa mencapai tujuan pengajaran secara optimal.

Sesuai dengan karakteristik KTSP MTs Jam'iyah Mahmudiyah yang memuat evaluasi/penilaian hasil belajar ranah kognitif, afektif dan psikomotorik. Dalam hal ini ada bentuk penilaian yang digunakan, yaitu:

a) Evaluasi Proses Belajar. Evaluasi Proses Belajar merupakan suatu proses untuk menentukan jasa, nilai atau memanfaatkan kegiatan penilaian dan atau prngukuran. Penilaian berbentuk tes dan menggunakan instrumen lain yaitu portofolio. Hal ini diselenggarakan agar kompetensi setiap mata pelajaran yang mencakup pengetahuan, sikap dan keterampilan yang tercermin dalam tindakan dan perilaku, sehingga guru mata pelajaran memantau peserta didik dan mengevaluasi secara menyeluruh baik di madrasah dan lingkungan sekitar. Di MTs Jam'iyah Mahmudiyah menentukan kriteria ketuntasan minimal belajar dalam memberikan penilaian tiga ranah, yaitu: (1) Ranah kognitif, dengan adanya tes tertulis. Ulangan harian minimal tiga kali dalam satu semester, apabila dalam ulangan harian peserta didik belum mencapai ketuntasan belajar, maka diadakan remidiasi sehingga ada nilai remidi. (2) Ranah afektif, dengan kriteria yang dinilai Kehadiran, kerajinan, kedisiplinan, keramahanketepatan mengumpulkan tugas-tugas, perhatian pada pelajaran (3) Ranah Psikomotorik, Penilaian ini dapat dinilai sesuai materi dan metode yang digunakan.

b) Evaluasi hasil belajar. Evaluasi hasil belajar merupakan proses untuk menentukan nilai belajar siswa melalui kegiatan peniliaian dan atau pengukuran hasil belajar hasil belajar, tujuan utama evaluasi untuk mengetahui tingkat keberhasilan yang dicapai oleh siswa setelah mengikuti suatu kegiatan pembelajaran, dimana tingkat keberhasilan yang tersebut kemudian ditandai dengan skala nilai berupa huruf atau kata atau simbol. Apabila tujuan utama kegiatan evaluasi hasil belajar ini sudah terealisasi maka hasilnya dapat difungsikan untuk berbagai keperluan. Evaluasi hasil belajar dapat dilakukan dengan berbagai cara: (1) Pertanyaan lisan di kelas baik berupa pemahaman konsep dan prisip. (2) Ulangan harian, ulangan harian ini dilaksanakan setiap selesai satu kompetensi dasar tugas individu. (3) Tugas individu, tugas ini diberikan kepada peserta didik dengan bentuk tugas atau soal uraian objektif atau non objektief. (4) Tugas kelompok, tugas ini digunakan untuk menilai kemampun kerja kelompok, bentuk tugas ini berupa uraian dengan tingak tinggi. (5) Ulangan semesteran atau mid semester yaitu ujian yang dilakukan pada tengah atau akhir semester.

Menurut peneliti Kegiatan evaluasi sudah dilaksanakan sesuai dengan tujuan pembelajaran untuk mengetahui pencapian standar kompetisi lulusan untuk mata pelajaran . Karena dalam pelaksanaanya evaluasi sudah mencakup hasil proses belajar dan hasil belajar, sehingga guru dapat mengetahui sejauh mana kefektifan pembelajaran dan hasil belajar selama kegiatan pembelajaran berlangsung.

Dengan penerapan fungsi-fungsi manajemen mulai dari perencanaan hingga sampai pada evaluasi pembelajaran diharapkan bisa meningkatkan prestasi belajar siswa di MTs Jam'iyah Mahmudiyah. Jika dilihat bahwa kemampuan intelektual yang sangat menentukan keberhasilan siswa dalam memperoleh prestasi. Untuk mengetahui berhasil tidaknya sesorang dalam belajar maka perlu dilakukan suatu evaluasi, tujuannya untuk mengetahui prestasi yang diperoleh siswa setelah proses belajar mengajar berlangsung.

Prestasi belajar merupakan tingkat kemanusiaan yang dimiliki siswa dalam menerima, menolak dan menilai informasiinformasi yang diperoleh pada proses pembelajaran, prestasi peserta didik sesuai dengan tingkat kederhasilan sesuatu dalam mempelajari materi pelajaran yang dinyatakan pada bentuk nilaiatau raport setiap bidang studi drtrlah mengalami proses pembelajaran. Prestasi belajar peserta didik dapat diketahui setelah diadakan evaluasi. Hasil dari evaluasi 
Jurnal Edumaspul, 5 (2), Year 2021 - 122

(Neliwati, Isra Adawiyah Siregar, Lia Ariska Ritonga)

dapat memperliatkan tentang tinggi atau rendahnya prestasi belajar siswa. Prestasi belajar siswa MTs Jam'iyah Mahmudiyah sudah cukup baik yang ditandai dengan nilai beberapa mata pelajaran yang sudah memenuhi KKM, Penerapan sikap dari materi pelajaran seperti mata pelajaran agama sudah dilaksanakan peserta didik dalam kehidupan sehari-hari baik di sekolah maupun di lingkungan keluarga dan masyarakat. Para siswa MTs Jam'iyah Mahmudiyah mempunyai prestasi yang cukup baik dengan ditandai ratarata nilai yang cukup memuaskan dan MTs Jam'iyah Mahmudiyah sudah cukup dikenal oleh masyarakat ini terbukti dengan adanya peserta didik bukan cuma dari satu desa tetap sudah lintas Kecamatan.

Ada beberapa Faktor Penghambat dan Pendukung kegiatan Pembelajaran di MTs Jam'iyah Mahmudiyah. Namun MTs Jam'iyah Mahmudiyah tetap selalu mengupayakan agar prestasi siwa terus meningkat seperti mengandalkan guru yang berkompenten, meningkatkan kemampuan siswa dalam mengikuti pembelajaran, membina hubungan yang baik dengan orangtua siswa serta mengajak para orangtua agar tetap terus melakukan pengawasan kepada peserta didik ketika berada dirumah. Inilah yang menjadi tugas yang akan selalu diupayakan oleh kepala sekolah dan seluruh staf guru MTs Jam'iyah Mahmudiyah.

Dalam Peningkatan Prestasi Belajar MTs Jam'iyah Mahmudiyah dilakukan dengan sistem pembiasaan. Pembiasaan yang sangat penting menjadi penilaian bagi peserta didik dengan memberikan pengontrolan ibadah harian di rumah yang diawasi oleh orang tua. Karena pendidikan agama di sekolah yang sangat pendek membutuhkan pengulangan dan pembiasaan di rumah. Pembiasaan menjadi salah satu nilai yang apat dijadikan nilai psikomotor bagi anak dihitung dengan nilai konsep ( Penguasaan materi). Kegaitan yang biasa dilakuan MTs Jam'iyah Mahmudiyah sebagai salah satu agenda rutin yang dimaksudkan dapat meningkatkan prestasi belajar Pendidikan Agama Islam yang diharapkan laksanakan oleh peserta didik tidak hanya di sekolah tetapi juga di laksanakan dalam kehidupan sehari-hari, peserta didik sudah terbiasa dengan pembiasaan ini sehingga peserta didik dapat melaksanakan dengan baik.

Dalam Peningkatan Prestasi Belajar siswa MTs Jam'iyah Mahmudiyah akan terlihat dari berhasil atau tidaknya peserta didik belajar yang terlihat dari usaha dan kegiatannya sendiri, di samping faktor kemauan, minat, ketekunan, tekad untuk sukses, dan cita-cita tinggi yang mendukung setiap usaha dan kegiatannya. Peserta didik akan berhasil kalau berusaha semaksimal mungkin dengan cara belajar yang efesien sehingga mempertinggi prestasi (hasil) belajar. Sebaliknya, jika belajar secara serampangan, hasilnyapun akan sesuai usaha itu, bahkanmungkin tifak menghailkan apa-apa. Hasil belajar juga tergantung pula pada cara-cara belajar yang gipergunakan. Oleh karena itu dengan mempergunakan cara-cara belajaryang efesien akan meningkatkan hasil belajar yang memuaskan.

Proses pembelajaran yang diarahkan untuk memberikan pengetahuan, sikap dan keterampilan kepada peserta didik untuk meningkatkan prestasi belajar, hal ini guru berupaya untuk menigkatkan hasil belajar agar prestasi belajar peseta didik dapat meningkat maka guru berusaha dengan upaya, yaitu: (1) Meningkatkan kemampuan diri, karena penguasaan materi dan kemampuan penyampaian materi ataupun keterampilan mengajar dapat mempengaruhi kinerja guru dalam proses pembelajaran, 2) Dedikasi (loyalitas), 3) Meningkatkan proses Pembelajaran, 4) Mengoptimalkan peran keluarga, dan lingkungan (budaya, masyarakat sosial), karena hal ini bisa mempengaruhi prilaku peserta didik dan dapat membentuk kepribadian peserta didik, 5) Manajemen yang baik, dengan adanya manajemen maka proses pembelajaran akan terarah dan berjalan dengan baik, karena manajemen merupakan proses perencanaan, pengorganisasian, pengarahan dan pengawasan sumber daya-sumber daya organisasi agar mencapai tujuan organisasi yang telah ditetapkan 6) Memacu kesiapan siswa dan selalu memberi motivasi siswa. Karena motivasilah yang mendorong siswa ingin melakukan kegiatan belajar. Guru juga memberikan kesempatan bagi peserta didik. Khususnya bagi peserta didik yang nilainya kurang memenuhi KKM dengan jalan memberikan jam pelajaran tambahan atau dengan les privat dan mengadakan remedial bagi peserta didik yang nilainya belum memenuhi KKM. Selain itu juga meningkatkan latihan siswa dalam mengajarkan soal-soal mata pelajaran ujian nasional. Dalam program pelaksanaannya MTs Jam'iyah Mahmudiyah mengadakan Try Out. 
Jurnal Edumaspul, 5 (2), Year 2021 - 123

(Neliwati, Isra Adawiyah Siregar, Lia Ariska Ritonga)

Upaya yang dilakukan baik dari Kepala Sekolah, waka Kurikulum dan guru-guru sudah dijalankan dengan baik dengan meningkatnya hasil belajar siswa dan hasil belajar yang telah memenuhi KKM yang telah ditetapkan yaitu nilai rata-rata pelajaran.

\section{Simpulan}

Berdasarkan hasil penelitian tentang manajemen pembelajaran dalam peningkatan prestasi belajar PAI di MIN Kalibuntu Wetan Kendal yang didukung oleh landasan teori, maka penulis dapat mengambil kesimpulan sebagai berikut: Pelaksanaan Manajemen pembelajaran secara umum sudah cukup baik, dengan ditandai perencanaan yang mencakup program tahunan, semesteran, silabus, kalender pendidikan, dan RPP, pada perencanaan masih ada cela yang kurang baik, dikarenakan masih banyak program yang belum dirancang dan dibuat. Pelaksanaan pembelajaran yang meliputi pengelolaan kelas dan peserta didik yang terdiri dari sebelum pembelajaran, inti pembelajaran dan tindak lanjut. Evaluasi yang mencakup evaluasi proses pembelajaran dan hasil belajar. Prestasi belajar sebagai hasil yang dicapai oleh peserta didik setelah mengalami suatu proses belajar dalam jangka tertentu, hasil belajar Pendidikan Agama Islam (PAI) siswa mencakup ranah kognitif, afektif dan psikomotorik. Prestasi belajar PAI di MIN Kalibuntu Wetan Kendal sudah cukup baik yang ditandai dengan: Nilai Pelajaran PAI siswa sudah memenuhi taget KKM, penerapan amalan Agama sudah dilaksanakan dalam kehidupan seharihari peserta didik dan siswa MIN Kalibuntu Wetan telah menjuarai lombalomba PAI dalam even-even dengan predikat baik.

\section{Daftar Pustaka}

Daryanto \& Mohammad Farid. 2013. Konsep Dasar Manajemen Pendidikan di Sekolah. Yogyakarta : Gava Media.

Hery Tarno, Daryanto. 2015. Pengelolaan Budaya Dan Iklim Sekolah. Yogyakarta: Gava Media.

Marno \& Triyo Supriyatno. 2008. Manajemen dan Kepemimpinan Pendidikan Islam. $\mathrm{h}$. 138.
Maryamah, Eva "Pengembangan Budaya Sekolah". Tarbawi. Vol. 2 No. 02, JuliDesember.

Rafiq, Ainur. 2007. Pengaruh Dimensi Kepercayaan (Trust)Terhadap

Partisipasi Pelanggan ECommerce (Studi Pada Pelanggan E-Commerce Di Indonesia) [tesis]. Universitas Brawijaya, Malang.

Rusman. 2012. Model-model Pembelajaran. Jakarta: RajaGrafindo Persada.

Umam, Khaerul. 2012. Manajemen Organisasi. Bandung : Pustaka Setia.

Wibowo, Agus. 2012. Menjadi Guru Berkarakter. Yogyakarta: Pustaka Pelajar.

Wong, David. "Pengaruh Ability, benevolence dan Integrity terhadap Trust, Serta Implikasinya Terhadap Partispasi Pelanggan E-Commere”. Jurnal Riset Manajemen Dan Bisnis, Vol. 2, No. 2, Juni 2017.

Yusuf, Choirul Fuad. 2010. Budaya Sekolah dan Mutu Pendidikan. Jakarta: Pena Citrasatria.

Suryobroto, Proses Belajar Mengajar di Sekolah, (Jakarta: PT. Rineka Cipta, 2002), Cet. I, hlm. 27.

Nganimun Naim dan Achmad Patoni, Materi Penyusunan Desain Pembelajaran

Pendidikan Agama Islam (MPDP-PAI), (Yogjakarta: Pustaka Pelajar, 2007s), hlm. 21-24.

\section{Profil Penulis}

Neliwati, lahir di Medan pada tanggal 12 Maret 1970, saat ini sebagai Dosen di Universitas Islam Negeri Sumatera Utara Medan.

Isra Adawiyah Siregar, lahir di Binanga pada tanggal 28 November 1997, saat ini sedang melanjutkan studi di Universitas Islam Negeri Sumatera Utara Medan.

Lia Ariska Ritonga, lahir pada tanggal 30 April 1994, saat ini sedang melanjutkan studi di Universitas Islam Negeri Sumatera Utara Medan. 